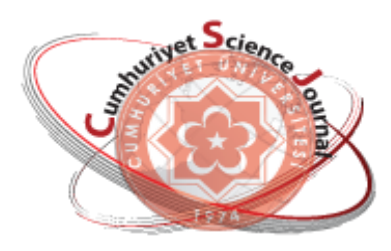

e-ISSN: 2587-246X

ISSN: $2587-2680$

\section{Cuculaniyet Seionce Journal $\operatorname{csg}$}

Cumhuriyet Sci. J., Vol.39-3(2018) 694-702

\title{
New Composite, Poly(Hydroxyethylmethacrylate-Expanded Perlite), for Single step Separation of Egg White Lysozyme
}

\author{
Birnur AKKAYA ${ }^{1 *}$, Recep AKKAYA ${ }^{2}$ \\ ${ }^{1}$ Cumhuriyet University, Faculty of Science, Department of Molecular Biology and Genetics, Sivas, Turkey \\ ${ }^{2}$ Cumhuriyet University, Faculty of Medicine, Basic sciences division, Department of Biophysics, Sivas, Turkey \\ Received: 14.05.2018; Accepted: 05.07.2018 \\ http://dx.doi.org/10.17776/csj.423415
}

\begin{abstract}
In this study, we investigated adsorption behaviour of lysozyme on poly(hydroxyethylmethacrylateexpanded perlite) [P(Hema-Ep)]. For this purpose, we synthesized P(Hema-Ep) composite by bulk polymerization and it was characterized by SEM, FTIR and swelling ratio. The fresh chicken egg white lysozyme was used as a model protein, had an isoelectric point (pI) 10.7 and molecular weight (MW) $14 \mathrm{kDa}$. Adsorption capacity was found $51 \mathrm{mg} \mathrm{g}^{-1}$ at room temperature and in $0.1 \mathrm{M} \mathrm{pH}=8.0$ phosphate buffer. Experiments on desorption and reusability were also performed. It appears that $\mathrm{P}$ (Hema-Ep) composites can be used ten times without lost of efficiency. Lysozyme purification, without causing any denaturation, can be performed from chicken egg white by using this new synthesized composite in a single step.
\end{abstract}

Keywords: Hydroxyethylmethacrylate, Lysozyme, Perlite, Purification.

\section{Poli(Hidroksietilmetakrilat-Genişletilmiş Perlit) Kompoziti ile Yumurta Akından Lizozimin Tek Basamakta Saflaştırılması}

Özet. $\mathrm{Bu}$ çalışmada poli(hidroksietilmetakrilat-genişletilmiş perlit) $\mathrm{P}($ Hema-Ep) kompozit materyali kullanılarak sulu çözeltiden lizozim adsorpsiyonu çalışıldı. Bu amaçla öncelikle P(Hema-Ep) kompoziti sentezlendi ve SEM, FTIR ve şişme testleri ile karakterizasyonu yapıldı. İsoelektrik noktası 10.7 (pI) ve molekül kütlesi 14 kDa olan tavuk yumurta beyazı lizozimi, enzimi model protein olarak kullanıldı. Oda sicaklığında ve 0.1 M pH:8.0 fosfat tamponunda gerçekleştirilen deney sonucunda adsorpsiyon kapasitesi $51 \mathrm{mg} \mathrm{g}^{-1}$ olarak bulundu. Desorpsiyon ve tekrar kullanılabilirlik deneyleri yapıldı. Sentezlenen P(Hema-Ep) kompoziti verimini kaybetmeden on kere tekrar kullanılabilir olduğu saptand1. Sentezlenen bu yeni kompozit ile lizozim enzimi tek basamaka saflaştırıldı.

Anahtar Kelimeler: Hidroksietilmetakrilat, lizozim, perlit, saflaştırma.

\section{INTRODUCTION}

Lysozyme (EC 3.2.1.17), damages bacterial cell walls by catalyzing hydrolysis of 1,4-beta-linkages between $\mathrm{N}$-acetylmuramic acid and N-acetyl-Dglucosamine residues in a peptidoglycan and between $\mathrm{N}$-acetyl-D-glucosamine residues in chitodextrins [1]. Lysozyme can be found in a number of secretions such as tears, saliva, human milk, mucus and large amounts are found in egg white [2]. Because of cell damaging properties, lysozyme is used as a cell disrupting agent, antibacterial agent, food additive, drug and many additional applications in the literature [3]. There are wide range of methods that are used to isolate lysozyme. Some of these methods are: Aqueous biphasic system for lysozyme separation studies [4], affinity cryogel and composite cryogel for lysozyme purification [5-7]. In addition, dye- 
attached nanoparticles were used for lysozyme seperation [8].

An amorphous volcanic rock, perlite, has water content as $5 \%$ and silicate content more than $70 \%$. This naturally occuring volcanic rock has a property of expansion after heating between 850 and $900{ }^{\circ} \mathrm{C}$ as it loses the water trapped within its structure and becomes a relatively light, white mineral called expanded perlite [9]. Perlite mainly composed of aluminium silicate and the silanol groups formed by silicon atoms on the surface of perlite that gives the adsorptive properties to perlite. Its surface's charge can be changed (more negative or positive) according to the $\mathrm{pH}$ of the medium. Thus surface charge depent on the $\mathrm{pH}$ [10]. In addition, its surface can be modified by functional groups for high protein adsorption.

Perlite have got some advantages such as, low cost, resistance to microbial attacks, mechanical stability, high surface area in comparison with inorganic adsorbents such as silica gels, alumina and zeolites [11]. Because of nice adsorptive features, expanded perlit is effectively used in the food industry such as processing of vegetable fat, juice and beer [10]. Moreover, it is also used as a high performance fillers, fitlers for chemical industry [9]. Silica are used as a matrix for protein separation and enzyme immobilization [12-14]. Although there are plenty of studies about lysozyme adsorption on silica containing materials $[15,16]$. Our study describe for the first time, lysozyme adsorption is studied on expanded perlite (natural material that contain silica groups) composite.

In this work, $\mathrm{P}$ (Hema-Ep) composite was used for lysozyme adsorption studies which was performed at aqueous solution in batch system. For this purpose, firstly $\mathrm{P}$ (Hema-Ep) composite was synthesized by bulk polymerization and characterized by SEM (Scanning electron microscopy,) FTIR and swelling ratio. Then composites were used for adsorption studies. Following adsorption experiments, desorption and resorption studies were performed.

\section{MATERIALS AND METHODS}

\subsection{Materials}

Lysozyme (chicken egg white, EC 3.2.1.17), ethylene glycol dimethacrylate (EGDMA), TEMED were obtained from Sigma-Aldrich. Expanded perlite (Ep) was obtained from Etibank (Izmir, Turkey). Ammonium persulfate (APS) were purchased from Merck (Germany).

\subsection{Preparation of $\mathbf{P}($ Hema-Ep) composite}

After washing step the mineral was dried for $24 \mathrm{~h}$ at $110{ }^{\circ} \mathrm{C}$ and then prepared in 100 mesh-size [17]. To prepare $\mathrm{P}(\mathrm{Hema}-\mathrm{Ep})$ composite by bulk polymerization following experimental procedure was applied: $2 \mathrm{~g}$ of Ep and $10 \mathrm{~mL}$ Hema solution ( 1/3 Hema (v/v)), 8 mL EGDMA as a crosslinker, $500 \mu \mathrm{g}$ APS as a starter, and $200 \mu \mathrm{L}$ TEMED as a accelerator were mixed. The obtained mixture was stirred for $4 \mathrm{~h}$ at $25^{\circ} \mathrm{C}$. The product, $25 \mathrm{~g}$ of $\mathrm{P}$ (Hema-Ep) composite, was washed and then dried.

\subsection{Characterization of $\mathrm{P}(\mathrm{Hema}-\mathrm{Ep})$ composite}

For screening surface morpholgy of the $\mathrm{P}(\mathrm{Hema}-$ Ep) composites SEM analysis was used. The composite was coated with a thin layer of gold under reduced pressure, and their surface morphology was visualized using SEM (JEOL/JSM-6335F).

Chemical structure of $\mathrm{P}(\mathrm{Hema}-\mathrm{Ep})$ was characterized by using FTIR spectrometry (Mattson 1000, UK). The composite was prepared as $\mathrm{KBr}$ pellet and spectra were taken five times using $4 \mathrm{~cm}^{-1}$ resolution and $400-4000 \mathrm{~cm}^{-1}$ frequency range.

Similar particle size of newly synthesized $\mathrm{P}$ (HemaEp) composite was prepared by using Tyler Standard sieves (Quantachrome Instruments).

Swelling ratio of $\mathrm{Ep}, \mathrm{P}(\mathrm{Hema})$ and $\mathrm{P}(\mathrm{Hema}-\mathrm{Ep})$ composite were determined as following procedure: $1.0 \mathrm{~g}$ of dry composite was placed into distilled water and kept at $25 \pm 0.5^{\circ} \mathrm{C}$. Swollen composite was taken and weighed. The weight ratios of dry and swollen samples were recorded. 
The swelling ratio of the swollen composite was calculated using the equation 1 .

Swelling ratio $(\%)=\left[\left(\mathrm{W}_{\mathrm{f}}-\mathrm{W}_{\mathrm{o}}\right) / \mathrm{W}_{\mathrm{o}}\right] \times 100$

Where Wo and Wf are the weight of the composites, before and after swelling, respectively.

All experiments were always performed in triplicate.

\subsection{Adsorption}

To investigate adsorption behaviour of lysozyme on the $\mathrm{P}$ (Hema-Ep) composite; $10 \mathrm{ml}$ of lysozyme solution were incubated with composite which magnetically stirred at $100 \mathrm{rpm}$ at $25^{\circ} \mathrm{C}$ during $2 \mathrm{~h}$ (i.e.,equilibrium time), in a flask. The initial concentration effects of lysozyme on adsorption capacity was performed by changing the initial concentration of lysozyme between 0.3 and 3.0 $\mathrm{mg} / \mathrm{ml}$ values. Bradford reagent was used for determination of lysozyme concentration at 595 nm. Following equation was used for determination of adsorption capacity:

$\mathrm{Q}=\left(\mathrm{C}_{\mathrm{o}}-\mathrm{C}\right) \times \mathrm{V} / \mathrm{m}$

Q ; mg adsorbed lysozyme per gram of adsorbent, $\mathrm{Co}$ and $\mathrm{C}$; initial and final concentration of lysozyme $(\mathrm{mg} / \mathrm{ml})$, respectively. $\mathrm{V}$; medium volume $(\mathrm{ml}) ; \mathrm{m}$; the amount of adsorbent $(\mathrm{g})$.

Effects of $\mathrm{pH}$, temperature and ionic strength on lysozyme adsorption on to P(Hema-Ep) composites were studied. The acidity of the solution was changed between 6.0 and 11.0 by using different buffer systems, phosphate buffer (0.1 M pH 6.0-8.0), and carbonate buffer (0.1 M $\mathrm{pH} 9,10,11)$; The temperature effect on lysozyme adsorption capacity was carried out at three different temperatures, $23-33-43^{\circ} \mathrm{C}$, in $0.1 \mathrm{M} \mathrm{pH}$ 8.0 phosphate buffer containing $1.0 \mathrm{mg} / \mathrm{ml}$ lysozyme solution. The ionic strength effect on lysozyme adsorption capacity was studied in the range of $0.0-1.0 \mathrm{M} \mathrm{NaCl}$ containing solution.

\subsection{Desorption and resorption}

To investigate the resorption cyle number of the $\mathrm{P}($ Hema-Ep) composite, resorption experiments were performed ten times by using the same composites after adsorption and desorption which is performed in $1.0 \mathrm{M} \mathrm{NaCl}$ containing aqueous solution as desorption agent. Lysozyme adsorbed $\mathrm{P}$ (Hema-Ep) composites were placed in the desorption medium and stirred for $1 \mathrm{~h}$ at $25^{\circ} \mathrm{C}$ at $100 \mathrm{rpm}$. The lysozyme concentration within the desorption medium was determined by method in section 2.4.

\subsection{Purified lysozyme activity}

Preparing egg white was described as the following experimental procedure was applied for preparing chicken egg white. Chicken egg white was separated from fresh eggs and mixed with a phosphate buffer (50\% (v/v), $100 \mathrm{mM}, \mathrm{pH} 8.0)$. The prepared egg white was homogenized in an ice bath and centrifuged at $4^{\circ} \mathrm{C}$ at $10,000 \mathrm{rpm}$ for 30 min. $100 \mathrm{mg} \mathrm{P}(\mathrm{Hema}-\mathrm{Ep})$ microcomposites were stirred with $10 \mathrm{ml}$ of prepared egg white solution for $1.5 \mathrm{~h}$ in a container magnetically at $150 \mathrm{rpm}$. The $\mathrm{P}$ (Hema-Ep) composites were next washed and removed unbound proteins centrifugation. Then, for desorption of lysozyme from lysozyme adsorbed $\mathrm{P}(\mathrm{Hema}-\mathrm{Ep})$ composite, it was placed in the desorption medium and stirred for $1 \mathrm{~h}$ at $25{ }^{\circ} \mathrm{C}$ at $100 \mathrm{rpm}$. The desorption of lysozyme from $\mathrm{P}$ (Hema-Ep) composite was carried out in $1.0 \mathrm{M}$ $\mathrm{NaCl}$. The lysozyme activity was determined by using optical density measurements at $450 \mathrm{~nm}$ by spectrophotometer, and the rate of decrease of culture of Micrococcus lysodeikticus cells suspended in the phosphate buffer $(0.1 \mathrm{M}, \mathrm{pH} 8.0)$ was followed for $5 \mathrm{~min}$ after addition of lysozyme. One enzyme unit $(\mathrm{U})$ is the amount of enzyme that decrease of absorbance as 0.001 units per minute (at $\mathrm{pH} 8.0,25^{\circ} \mathrm{C}$ ) in OD 450.

\section{RESULTS AND DISCUSSION}

\subsection{Characterization of $\mathbf{P}(\mathrm{Hema}-\mathrm{Ep})$ composite}

\subsubsection{Interaction sites of $\mathrm{P}(\mathrm{Hema-Ep})$ composite}

Isomorphous substitution is a replacement that replacing divalent ions with tetravalent silicon in the tetrahedral sheet and obtain a net negative charge on the clay surface [18-21]. Positive charged groups or ions can be adsorbed onto the 
negative charged Ep surface due to the ionic interactions (Fig.1). Although "Hema", by itself, had inert features for adsorption, it might have increased the adsorption capacity of "Ep" in
$\mathrm{P}$ (Hema-Ep) by enabling the expansion basal spacing of "Ep"'[17,22].

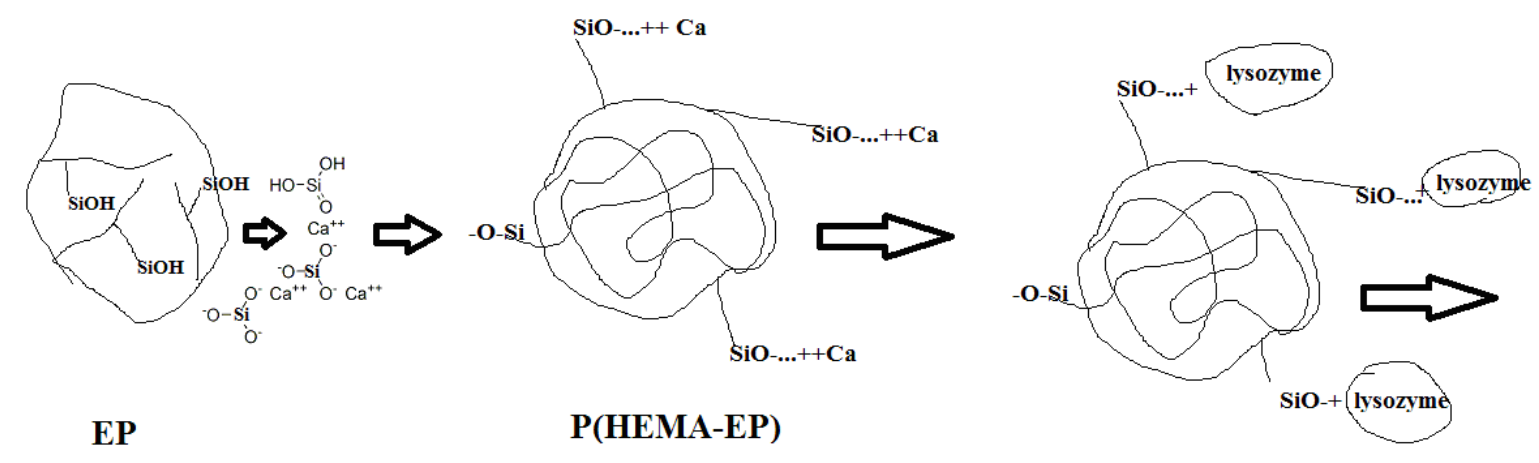

Figure 1. Presentation of interaction between $\mathrm{P}(\mathrm{Hema}-\mathrm{Ep})$ and lysozyme.

$\mathrm{P}($ Hema-Ep) was containing 1:3(w/w) of the Ep. The swelling ratio of Ep and $\mathrm{P}(\mathrm{Hema})$ compounds were found as $121 \%$ and $98 \%$, respectively. A hypothetical expansion value of $179 \%$ was estimated for $\mathrm{P}(\mathrm{Hema}-\mathrm{Ep})$. According to this result, hydrophilic nature of the composite $\mathrm{P}($ Hema-Ep) was enhanced in comparison to its individual components that might be attributed to the hydrophilic contribution of silanol groups of Ep in $\mathrm{P}(\mathrm{Hema}-\mathrm{Ep})$ to $\mathrm{P}(\mathrm{Hema})$. This large internal surface area may also provide a high ion-transfer rate. Particle size of newly synthesized $\mathrm{P}(\mathrm{Hema}-$ Ep) composite was prepared by using Tyler Standard sieves and sieved to a particle size of 150 mesh, and stored in a polypropylene container.

\subsubsection{Scanning Electron Microscobic (SEM) analysis of $\mathrm{P}(\mathrm{Hema}-\mathrm{Ep})$ composite}

The SEM picture of $\mathrm{P}(\mathrm{Hema}-\mathrm{Ep})$ composite (Fig. 2) shows surface of the composite. The homogeneous view of $\mathrm{P}$ (Hema-Ep) composite was seen clearly in Fig. 2. The presence of polyhydroxyethylacrylamide in the perlite structure behaves as a filler between two perlite layers and by incorporation of polymeric filler, the foliated structure of perlite is lost and the perlite gains a rough surface [17].

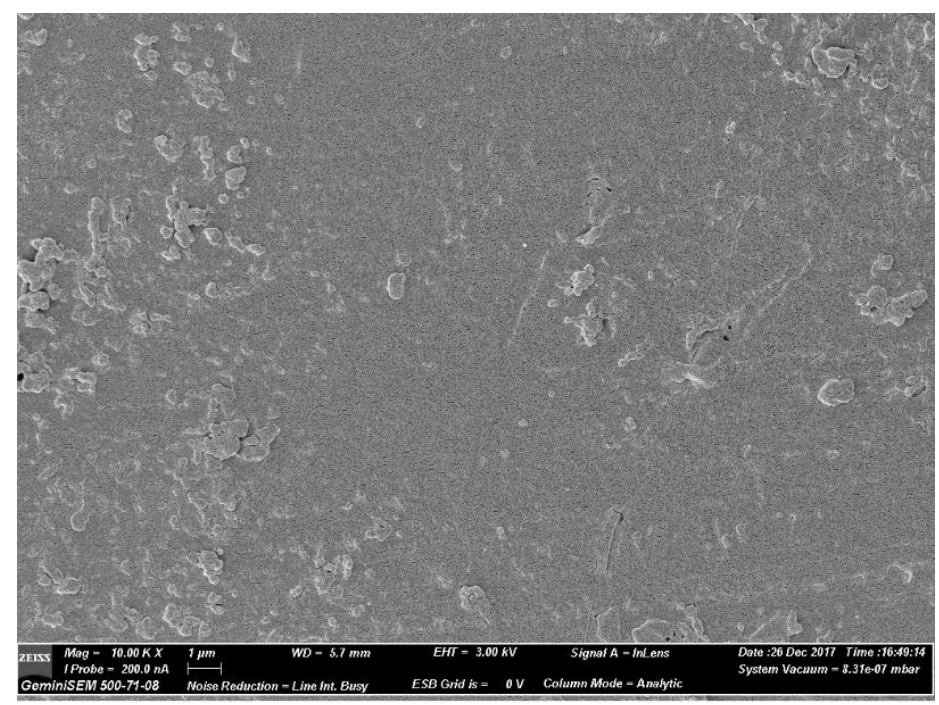

Figure 2. Scanning electron micrograph of $\mathrm{P}(\mathrm{Hema}-\mathrm{Ep})$ composite. 


\subsubsection{FTIR}

The FTIR spectra of $\mathrm{P}(\mathrm{Hema}-\mathrm{Ep})$ is shown in Fig. 3. The characteristic structure of the FTIR spectra of $\mathrm{P}$ (Hema-Ep) composite shows peaks at 3,190 $\mathrm{cm}^{-1}$ as --Si-OH stretching vibrations. $1,170 \mathrm{~cm}^{-1}$, and $1,650 \mathrm{~cm}^{-1} \quad(-\mathrm{Al}-\mathrm{OH}$ and $--\mathrm{AI}-2(\mathrm{OH})$ stretching vibrations) due to the presence of predominant silanol groups and hydroxyl groups, respectively. The surface silicon atoms try to keep on their tetrahedral coordination with oxygen. Silanol groups are formed by attachment to monovalent hydroxyl groups, at room temperature [9]. It was reported that amino acids which were positively charged, interacts with perlite via inner and outer layer through hydrogen bonding and cationic exchange interactions [23].

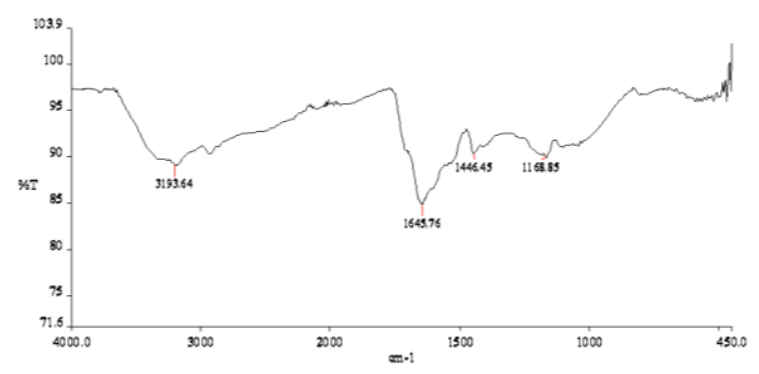

Figure 3. FTIR analysis of p(hema-ep) composite.

\subsection{Lysozyme adsorption}

\subsubsection{Effect of $p H$}

Lysozyme adsorption on to the $\mathrm{P}(\mathrm{Hema}-\mathrm{Ep})$ composite was $\mathrm{pH}$ dependent as illustrated in Fig. 4. It increased from $\mathrm{pH} 6.0$ to 8.0 and decreased after this $\mathrm{pH}$ value (Fig.4), means that the adsorption capacity of lysozyme was maximum at the $\mathrm{pH}$ values 8.0 which affects the end surface charge of the Ep and the degree of ionizable groups of lysozyme. Owing to the strong electrostatic interaction between negatively charged surface of $\mathrm{P}($ Hema-Ep) composite and the positively charged lysozyme, the high adsorption capacity was obtained at $\mathrm{pH}$ 8.0. As the $\mathrm{pH}$ of the solution increased up to 8.0, interaction increased between the positive charges on the surface of lysozyme and the negative charges on the surface of P(Hema-Ep) composites. After $\mathrm{pH}$ 8.0, ionizable basic groups of lysozyme ionized and because of decreasing pozitive charges of lysozyme, interaction between adsorbent and protein was decreased.

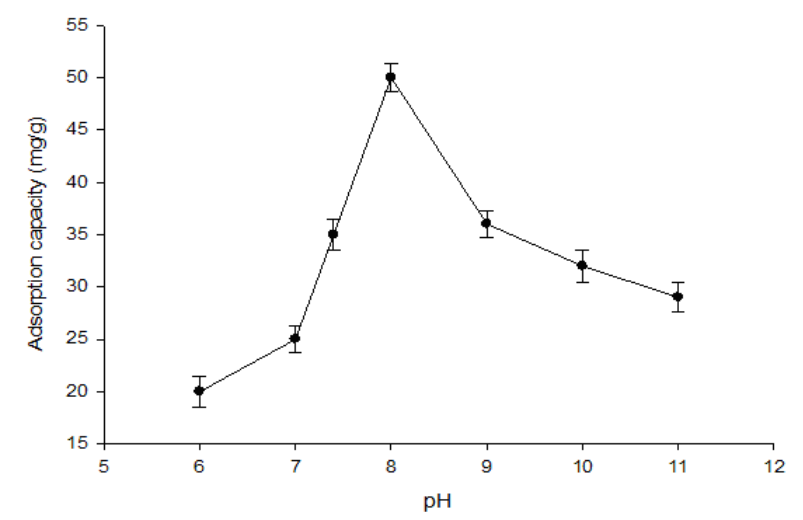

Figure 4. Effect of $\mathrm{pH}$ on adsorption. Lysozyme concentration: $1.0 \mathrm{mg} / \mathrm{ml}, \mathrm{T}=23{ }^{\circ} \mathrm{C}$.

\subsubsection{Effect of Initial Concentration}

In Fig.5, adsorption capacities of $\mathrm{P}(\mathrm{Hema}-\mathrm{Ep})$ composites were given as a function of lysozyme concentration. The lysozyme concentration in solution increases and adsorption capacity of the composites were increased (Fig.5). Maximum adsorption capacities of $\mathrm{P}(\mathrm{Hema}-\mathrm{Ep})$ composites was determined as $51 \mathrm{mg} \mathrm{g}^{-1}$. This is due to the saturation at concentrations around $2.0 \mathrm{mg} \mathrm{g}^{-1}$ of the binding sites on the $\mathrm{P}(\mathrm{Hema}-\mathrm{Ep})$ composites. Shao et. al. were used the PAA-modified Fe3O4@silica microspheres for lysozyme separation, and they found that the maximum binding capacity was $127 \mathrm{mg} \mathrm{g}^{-1}$ [15]. H. Guo et al. were used lysozyme imprinted magnetic chitosan microspheres and the results showed that the maximum binding capacity was $129.8 \pm \mathrm{mg} \mathrm{g}^{-1}$ [24].

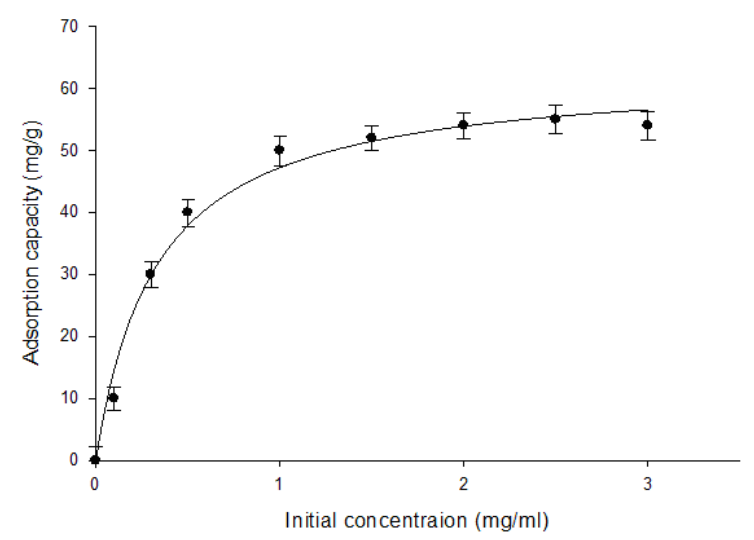

Figure 5. Effect of initial Lysozyme concentration. $\mathrm{pH} 8.0$ (100 mM phosphate buffer), $\mathrm{T}=23^{\circ} \mathrm{C}$. 


\subsubsection{Effect of Temperature}

Effect of temperature on lysozyme adsorption from aqueous solution is illustrated in Fig. 6. The effect of temperature on lysozyme adsorption was investigated at different temperatures, $23-33-43{ }^{\circ} \mathrm{C}$, and as seen in Figure 6, lysozyme adsorption on to the $\mathrm{P}$ (Hema-Ep) composite is dependent on temperature. Maximum adsorption capacity was measured at $23{ }^{\circ} \mathrm{C}$ (Fig. 6). Adsorption capacity was decreased by increasing temperatures. This could be due to the surface silicon atoms which try to keep on their tetrahedral coordination with oxygen. Silanol groups are formed by attachment to monovalent hydroxyl groups, at room temperature [9]. The presence of predominant silanol groups and hydroxyl groups in the composite serves as an active binding site for metals and accordingly for positive charged protein molecules. At the higher temperatures, there is also adsorption on to the $\mathrm{P}$ (Hema-Ep) composites. This could be due to lysozyme stability. Some materials such as perlite were used for protein stabilization [25].

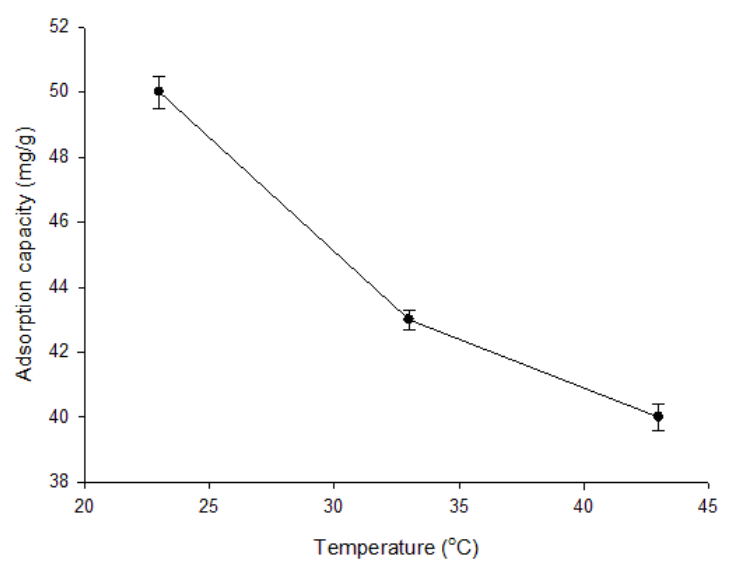

Figure 6. Effect of temperature. Lysozyme concentration: 1.0 $\mathrm{mg} / \mathrm{ml}, \mathrm{pH} 8.0$ (100 $\mathrm{mM}$ phosphate buffer).

\subsubsection{Effect of Ionic Strength}

The studies of ionic strength effect on adsorption capacity of lysozyme on to the $\mathrm{P}(\mathrm{Hema}-\mathrm{Ep})$ composites were investigated in the presence of different $\mathrm{NaCl}$ concentrations (from 0.0 to $1.0 \mathrm{~mol}$ $\left.\mathrm{L}^{-1}\right)$. When the concentration of $\mathrm{NaCl}$ was increased from 0.0 to $1.0 \mathrm{~mol} \mathrm{~L}^{-1}$ the adsorption capacity of lysozyme decreased (from 50 to 5) $\mathrm{mg}$ $\mathrm{g}^{-1}$ as in mentioned in the literature [26-29], which shows that anions and cations affects the interaction between lysozyme and $\mathrm{P}(\mathrm{Hema}-\mathrm{Ep})$ composites (Fig. 7). In fact, electrostatic interactions were the basic interaction between lysozyme and $\mathrm{P}(\mathrm{Hema}-\mathrm{Ep})$ composites in the adsorption process. In addition, the adsorption process could be taking place on the surface of the $\mathrm{P}$ (Hema-Ep) composites. Thus, salt ions may interact with metal ions of composites at high salt concentrations and this could block the surface of the composites for interaction of lysozyme molecules.

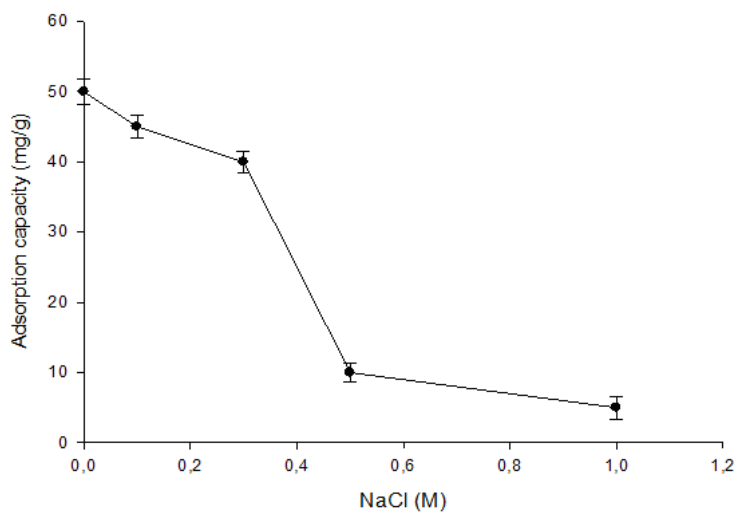

Figure 7. Effect of ionic strength. Lysozyme concentration: $1.0 \mathrm{mg} / \mathrm{ml}, \mathrm{pH} 8.0$ (100 mM phosphate buffer), $\mathrm{T}=23{ }^{\circ} \mathrm{C}$.

\subsubsection{Desorption and Resorption}

In this work, $97 \%$ of the adsorbed lysozyme molecules were desorbed easily from the $\mathrm{P}(\mathrm{Hema}-$ Ep) composites during $1 \mathrm{~h}$ when $1.0 \mathrm{M}$ sodium chloride was used as a desorption agent in the 100 $\mathrm{mM}$ pH 8.0 phosphate medium (Fig. 8). The desorption of lysozyme from the $\mathrm{P}(\mathrm{Hema}-\mathrm{Ep})$ composites was performed in a batch system. On the basis of the research results (Fig. 8), it can be concluded that sodium chloride was a suitable desorption agent. To demonstrate the reusability of the $\mathrm{P}($ Hema-Ep) composites, the adsorption/desorption cycle was repeated 10 times with the same $\mathrm{P}$ (Hema-Ep) composites from an aqueous lysozyme solution (Fig.8). There was no significant loss in the adsorption capacity of the composites after 10 cycles. 


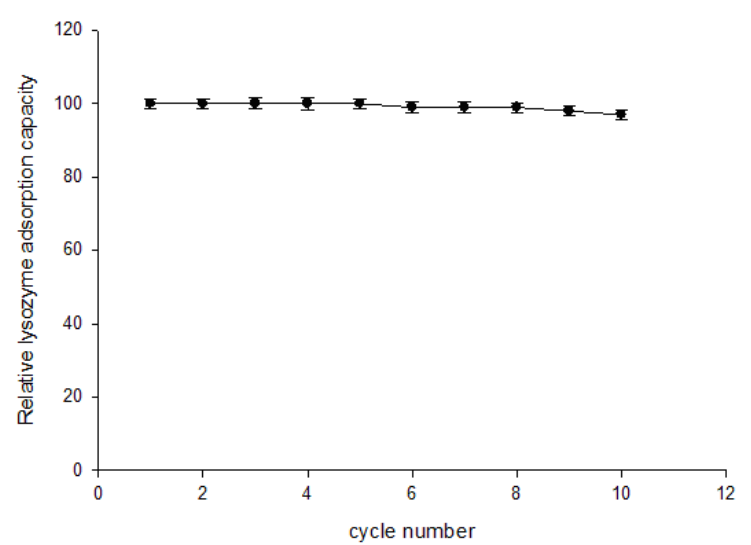

Figure 8. Reusability of $\mathrm{P}(\mathrm{Hema}-\mathrm{Ep})$ composite.

\subsection{Lysozyme activity}

Chicken egg white's protein components were ovalbumin (pI:4.5), ovotransferrin (pI:6.1), ovomucoid (pI:4.5) and lysozyme (pI:10.7) [30,31]. The specific activity of the purified lysozyme with $\mathrm{P}($ Hema-Ep) composite was $50 \mathrm{U}$ $\mathrm{mg}^{-1}$ which was reported in literature [32].

\section{CONCLUSION}

In the last decade, there has been increasing interest in finding easily available, low-cost materials with high adsorption affinities such as bentonite, zeolite, chitosan, hydroxyapatite, and perlite. Due to large deposits of perlite in Turkey, perlite can be easily obtained. Perlite is one of the promising adsorbents but it was not used effectively for biomolecules. In this work, for the first time, it is used as a suitable and low-cost adsorbent for purification of lysozyme from egg white. The best efficiency of perlite is due to its rough structure and the presence of matrix of macro-pores in it that yields greater active surface area, enhancing adsorption. Composite materials were used in a various of protein purification applications in literature [3336]. The inert behavior of $\mathrm{P}(\mathrm{Hema})$ enables it to act as a matrix (host) within the composite, expanding the adsorbent capacity of Ep (guest) particles. Hence, by using P(Hema-Ep) composites lysozyme could be purified in a single step from diluted egg white.

\section{ACKNOWLEDGMENTS}

This work was supported by The Research Fund of Cumhuriyet University (CUBAP, project number F-421).

\section{REFERENCES}

[1]. Choonia H.S. and Lele S.S. Release of $\beta$ galactosidase by Permeabilization of Indigenously Isolated Lactobacillus acidophilus Using Lysozyme, Chem. Biochem. Eng. Q., 27 (2013) (4) 449-456.

[2]. Silvetti T., Morandi S., Hintersteiner M., Brasca M. Egg Innovations and Strategies for Improvements. Chapter 22-Use of Hen Egg White Lysozyme in the Food Industry. Institute of Sciences of Food Production, Italian National Research Council, Milan, Italy. (2017) Editors: Patricia Hester.

[3]. Pereira M.M., Cruz R.A.P., Almeida M.R., Lima Á.S., Coutinho J.A.P., and Freire M.G.. Single-Step Purification of Ovalbumin from Egg White Using Aqueous Biphasic Systems. Process Biochem. (2016) 51(6): 781-791.

[4]. Lu Y., Lu W., Wang W., Guo Q., Yang Y. The optimization of aqueous two-phase extraction of lysozyme from crude hen egg white using response surface methodology. $\mathbf{J}$ Chem Technol Biotechnol. 88 (2013) 415421.

[5]. Erol K., Köse K., Uzun L., Say R., Denizli A. Polyethyleneimine assisted-two-step polymerization to develop surface imprinted cryogels for lysozyme purification, Colloids and Surfaces B: Biointerfaces 146 (2016) 567-576.

[6]. Veríssimo L.A.A., Paganoto F.S., Mol P.C.G., Fontan R.C.I., Minim V.P.R. and Minim L.A. Preparation of an affinity cryogel column for lysozyme purification. Sep. Scie. Tech. (2017) 52(12), 1973-1982.

[7]. Türkmen D., Denizli A., PHEMA based composite cryogels with loaded hydrophobic beads for lysozyme purification. Colloids and Surfaces B: Biointerfaces 123 (2014) 859-865. 
[8]. Uygun, M., Uygun, D.A. Altunbas, C., Akgol, S. and Denizli A. Dye Attached Nanoparticles M. for Lysozyme Adsorption. Sep.Scie. and Technol., 49(2014) 12701278.

[9]. Akkaya R., Akkaya B. New low-cost composite adsorbent synthesis and characterization. Desalin. Water Treat. 51 (2013) 3497-3504.

[10]. Alihosseini A., Taghikhani V., Safekordi A.A., Bastani D. Equilibrium sorption of crude oil by expanded perlite using different adsorption isotherms at $298.15 \mathrm{k}$ Int. J. Environ. Sci. Tech.7 (3)(2010) 591-598.

[11]. Pezzella C., Russo M.E., Marzocchella A., Salatino P., Sannia G. Immobilization of a Pleurotus ostreatus Laccase Mixture on Perlite and Its Application to Dye Decolourisation. BioMed Res. Int. 2014 (2014) 11.

[12]. Xia H., Wan G., Zhao J., Liu J., Bai Q., Preparation and characterization of monodisperse large-porous silica microspheres as the matrix for protein separation. Journal of Chromatography A, 1471 (2016) 138-144.

[13]. Thangaraj B., Jia Z., Dai L., Liu D., Du W.. Effect of silica coating on $\mathrm{Fe} 3 \mathrm{O} 4$ magnetic nanoparticles for lipase immobilization and their application for biodiesel production. Arab. J. Chem. (2016).

[14]. Tavares A.P.M., Rodríguez O., Fernández M. F.-, Domínguez A., Moldes D., Sanromán M. A., Macedo E. A. Immobilization of laccase on modified silica: stabilization, thermal inactivation and kinetic behaviour in 1-ethyl-3methylimidazolium ethylsulfate ionic liquid. Bioresour. Technol. 131 (2013) 405-412.

[15]. Shao D., Xu K., Song X., Hu J., Yang W., Wang C. Effective adsorption and separation of lysozyme with PAA-modified Fe3O4@silica core/shell microspheres. J. Colloid. Interf. Sci. 336 (2009) 526-532.

[16]. Czeslik C., R. Winter. Effect of temperature on the conformation of lysozyme adsorbed to silica particles. Phys. Chem. Chem. Phys. 3 (2001) 235-239.
[17]. Anirudhan T.S., Suchithra P.S., Rijith S. Colloids Surfaces A: Physicochem. Eng. Aspects, 326 (2008) 147-156.

[18]. Xifan S., Chun L., Zhansheng W., Xiaolin X., Ling R. and Hongsheng Z. Adsorption of Protein from Model Wine Solution by Different Bentonites. Chin. J. Chem. Eng., 15(5) 632-638 (2007).

[19]. Güngör N., Karaoğlan S. Interactions of polyacrylamide polymer with bentonite in aqueous system, Mater. Lett. 48 (2001) 168175.

[20]. Ju J.Y., Shen D.X. Exploitation and Application of Bentonite in Project, China Architecture Industry Press, Beijing (2003) (in Chinese).

[21]. Özcan A.S., Erdem B., Özcan A. Adsorption of Acid Blue 193 from aqueous solutions onto Na-bentonite and DTMA-bentonite J. Colloid Interf. Sci., 280 (2004) 44-54.

[22]. Celik A.G., Kilic A.M., Cakal G.O. Physicochemical Problems of MineralProcessing. Physicochem. Probl. Miner. Process. 49 (2013) 689-700.

[23]. Permanasari A., dan Zackiyah, 2006, Mekanisme Adsorpsi Diazinon pada Adsorben Histidin Bentonit. Proceeding Seminar Kimia UPIHKI.

[24]. Guo H., Yuan D., Fu G. Enhanced surface imprinting of lysozyme over a new kind of magnetic chitosan submicrospheres. J. Colloid Interf. Sci. 440 (2015) 53-59.

[25]. Sarmento M.R., Oliveira J.C., Boulton R.B. Selection of low swelling materials for protein adsorption from white wines. Int. J. Food Sci. Tech. 35 (2000) 41-47.

[26]. Sun J., Rao S., Su Y., Xu R., Yang Y. Magnetic carboxymethyl chitosan nanoparticles with immobilized metal ions for lysozyme adsorption. Colloids and Surf., A: Physicochem. Eng. Aspects 389 (2011) 97-103.

[27]. Basar N., Uzun L., Güner A., Denizli A. Lysozyme purification with dye-affinity beads under magnetic field. International Journal of Biological Macromolecules. Int. J. Biol. Macromol. 41 (2007) 234-242. 
[28]. Bayramoglu G., Y1lmaz M., Arıca M.Y. Affinity dye-ligand poly(hydroxyethyl methacrylate)/chitosan composite membrane for adsorption lysozyme and kinetic properties. Biochem. Eng. J. 13 (2003) 35-42.

[29]. Altıntaş E.B., Tüzmen N., Candan N., Denizli A. Use of magnetic poly(glycidyl methacrylate) monosize beads for the purification of lysozyme in batch systemJ. Chromatogr. B. 853 (2007) 105-113.

[30]. Abeyrathne E.D.N.S., Lee H.Y., Ham J.S., and Ahn D.U. Separation of ovotransferrin from chicken egg white without using organic solvents. Poult. Sci. 92 (2013) 10911097.

[31]. Abeyrathne E.D.N.S., Lee H.Y. and Ahn D.U. Sequential separation of lysozyme, ovomucin, ovotransferrin, and ovalbumin from egg white. Poult. Sci. 93 (2014) 10011009.

[32]. Karakisla M., Bayramoglu G., Arıca M.Y. Preparation of methacrylamide grafted and dye-ligand immobilized PET fibers: Studies of adsorption and purification of lysozyme.J. App. Poly. Sci. 108 (2008) 3313-3323.

[33]. Yun J., Xu L., Lin D.-Q., Yao K., Yao S.-J. Fabrication and characterization of cryogel beads and composite monoliths, in: Supermacroporous Cryogels, CRC Press, (2016) 113-146.

[34]. Göktürk I., Derazshamshir A., Y1lmaz F., Denizli A. Poly(vinyl alcohol)/polyethyleneimine (PVA/PEI) blended monolithic cryogel columns for the depletion of haemoglobin from human blood, Sep. Sci. Technol. 51 (2016) $1787-$ 1797.

[35]. Hajizadeha S., Kettisena K., Gramb M., Bülowa L., Yea L. Composite imprinted macroporous hydrogels for haemoglobin purification from cell homogenate. Journal of Chromatography A, 1534 (2018) 22-31.

[36]. Baydemir G., Türkoğlu E.A., Andaç M., Perçin I., Denizli A. Composite cryogels for lysozyme purification. Biotechnol Appl Biochem. (2015) 62(2)200-7. 